\title{
IN VITRO ANALYSIS OF ANTIMICROBIAL COMPOUNDS FROM ALSTONIA SCHOLARIS
}

\section{PRITHA CHAKRABORTHY, AAKANKSHA CHAND, SHAGUN SRIVASTAVA, RAMESH YADAV, DANNIE KINGSLEY, JAYANTHI ABRAHAM*}

Microbial Biotechnology Lab, School of Biosciences and Technology, VIT University, Vellore - 632 014, Tamil Nadu, India. Email: jayanthi.abraham@gmail.com

Received: 11 April 2016, Revised and Accepted: 16 April 2016

\section{ABSTRACT}

Objective: The increasing prevalence of drug-resistant pathogens has gained the attention of pharmaceutical and scientific communities toward potential antimicrobial agents from plant-derived sources. The present work deals with the extraction, screening, and characterization of antimicrobial compounds from Alstonia scholaris against various pathogenic micro-organisms.

Methods: The components of crude extracts obtained after soxhlet extraction of plants were characterized through thin layer chromatography (TLC) and gas chromatography-mass spectrometry (GC-MS). The antimicrobial effect was checked at different concentration against Bacillus subtilis MTCC 121, Staphylococcus aureus MTCC 96, Escherichia coli MTCC 43, Klebsiella pneumonia MTCC 432, Pseudomonas aeruginosa MTCC 424, and Streptococcus pyogenes MTCC 497.

Results and Conclusion: $A$. scholaris extract showed a significant antibacterial effect against selective pathogens. The bioactive compounds were separated and identified by TLC and GC-MS, respectively.

Keywords: Bioactive metabolites, Extraction, Bioactivity, Pathogens, Minimum inhibitory concentration.

(C) 2016 The Authors. Published by Innovare Academic Sciences Pvt Ltd. This is an open access article under the CC BY license (http://creativecommons. org/licenses/by/4. 0/) DOI: http://dx.doi.org/10.22159/ajpcr.2016.v9i5.12173

\section{INTRODUCTION}

The threat of infectious disease has substantially reduced, and the diseases that were thought to be controlled by antibiotics are rising in new forms, resistant to exiting antibiotics. The major problem of the emergence of resistant bacteria is due to misuse and overuse of antibiotics. The development of antibiotic resistance in bacteria is a major issue in the prevention of infectious diseases [1]. The spread of antibiotic drug resistance is predominant through nosocomial infections [2]. Nosocomial infections caused by Pseudomonas aeruginosa are often difficult to treat because this organism displays resistance to all commercially available antibiotics [3]. Medicinal plants are widely used either directly as folk medicine or indirectly by pharmaceutical preparation of modern medicines. Bioactive compounds have attracted the attention of pharmaceutical and scientific communities, and evidence has demonstrated the promising potential of antimicrobial plant-derived substances.

Alstonia scholaris has been well known for its therapeutic properties in the treatment of cancer, warts, hepatitis, and abdominal swelling. A. scholaris is used only for medicinal purposes, ranging from malaria and epilepsy to skin conditions and asthma. It is also known as bitter herb for treating skin disorders, malarial fever, urticaria, chronic dysentery, diarrhea, in snake bites, and for upper purification process of panchakarma. Plants derived compound of therapeutic value are mostly secondary metabolite. They have a wide activity range, according to the species, the topography and climate of the country of origin, and may contain different categories of active principles. This study deals with the extraction, screening, and characterization of antimicrobial active constituents present in leaves and flowers of $A$. scholaris against various pathogenic microorganisms as the biological active compounds from the bark of these plants have been previously studied by various researchers.

\section{METHODS}

\section{Sample collection}

The leaves and flowers of $A$. scholaris were collected freshly from plant nursery in VIT University, Vellore district of Tamil Nadu. The fresh leaves and flowers were properly washed with sterile water and shade dried at room temperature and then powdered mechanically using commercial electrical stainless steel blender.

\section{Extraction of plant samples}

The finely ground powder of plant material (30 g) was extracted with $n$-hexane and methanol subsequently in soxhlet extractor not exceeding the boiling point of the solvent for $8 \mathrm{hrs}$. The completely dried extracts were stored at $4^{\circ} \mathrm{C}$ for further experimental analysis [4].

\section{Phytochemical screening of crude plant extracts}

The phytochemical components of the medicinal plants were screened using the standard methods explained by Kamba and Hassan [5]. The components analyzed were saponins, steroids, cardiac glycosides, quinones, tannins, flavonoids, alkaloids, phenols, terpenoids, carbohydrates, and proteins.

\section{Detection of alkaloids}

Solvent free extract, $5 \mathrm{mg}$ was stirred with few $\mathrm{ml}$ of diluted hydrochloric acid and filtered. The filtrate was tested carefully with various alkaloidal reagents [6].

A. Hager's test: Filtrates were treated with Hager's reagent (saturated picric acid solution). The presence of alkaloids was confirmed by the formation of yellow colored precipitate.

B. Wagner's test: To few milliliter of filtrate, few drops of Wagner's reagent were added along the side of test tube. Reddish brown precipitates indicated positive test [7].

Wagner's reagent: Iodine (1.27 g) and potassium iodide (0.92 g) were dissolved in $5 \mathrm{ml}$ of water and made up to $100 \mathrm{ml}$ with distilled water.

Detection of carbohydrates and glycosides

About $5 \mathrm{mg}$ of extract was dissolved in $5 \mathrm{ml}$ of water and filtered. The filtrate was subjected to the following tests [8].

A. Fehling's test: $1 \mathrm{ml}$ of filtrate was boiled on water bath with $1 \mathrm{ml}$ of each of Fehling's solutions A and B. The appearance of red precipitate confirmed the presence of sugar. 
Fehling's solution A: Copper sulfate (34.66 g) was dissolved in distilled water and made up to $500 \mathrm{ml}$ using distilled water.

Fehling's solution B: Potassium sodium tartarate (173 g) and sodium hydroxide $(50 \mathrm{~g})$ were dissolved in water and made up to $500 \mathrm{ml}$.

B. Molish test: To $2 \mathrm{ml}$ of filtrate, two drops of an alcoholic solution of $\alpha$ napthol were added, the mixture was shaken well and $1 \mathrm{ml}$ of concentrated sulfuric acid was added slowly along the sides of test tube and allowed to stand. The formation of violet ring indicated the presence of carbohydrates.

\section{Detection of phytosterols}

Libermann Burchard's test

The extract (5 mg) was dissolved in $2 \mathrm{ml}$ acetic anhydride. To this, one or two drops of concentrated sulfuric acid were added slowly along the sides of the test tube. An array of color changes indicated the presence of phytosterols [9].

\section{Detection of phenolic compounds \\ Ferric chloride test}

The extract ( $2 \mathrm{mg}$ ) was dissolved in $5 \mathrm{ml}$ of distilled water. To this, few drops of neutral $5 \%$ ferric chloride solution was added. The appearance of green color indicated the presence of phenolic compounds [10].

\section{Detection of flavonoids \\ Alkaline reagent test}

Extracts were treated with few drops of sodium hydroxide solution. The formation of intense yellow color, which turned colorless on addition of dilute acid, that indicating the presence of flavonoids.

\section{Lead acetate test}

To $1 \mathrm{ml}$ of the plant, extract was taken in a test tube. To this $1 \mathrm{ml}$ of $5 \%$ lead acetate and the mixture was allowed to stand for few minutes. The formation of precipitates in the samples confirmed the presence of flavonoids.

\section{Detection of tannins}

About $0.5 \mathrm{~g}$ of extract was stirred with about $10 \mathrm{ml}$ of distilled water and then filtered. Few drops of $1 \%$ ferric chloride solution were added to $2 \mathrm{ml}$ of the filtrate. Formation of a bluish black, bluish green or green precipitate confirmed the presence of tannins.

\section{Detection of terpenoids (Salkowski test)}

About $2 \mathrm{ml}$ chloroform was added to the extract. Concentrated $\mathrm{H}_{2} \mathrm{SO}_{4}(3 \mathrm{ml})$ was carefully added to form a layer. The appearance of reddish brown coloration on the interface confirmed the presence of terpenoids.

\section{Detection of quinolones}

About $1 \mathrm{ml}$ of each extract was treated with $1 \mathrm{ml}$ of concentrated $\mathrm{H}_{2} \mathrm{SO}_{4}$. The red color developed indicates the presence of quinines.

\section{Detection of saponins}

About $1 \mathrm{ml}$ of extract is mixed with $2 \mathrm{ml}$ of distilled water. The mixture was shaken properly and allowed to stand for 10 minutes. $1 \mathrm{~cm}$ layer of foam was formed. If the layer was lasted for more than 10 minutes, it indicated the presence of saponins.

\section{Analytical methods}

Fractionation of the crude extract using thin layer chromatography (TLC)

Using pre-coated TLC F254 plates, the crude extract was fractionated using different combinations of toluene:ethyl-acetate:methanol (4:0.5:0.5) and hexane:ethyl acetate $(9: 1)$ as the mobile phase. Separated components were viewed in visible light, under ultraviolet at $360 \mathrm{~nm}$, by fluorescence quenching $<254 \mathrm{~nm}$. Separation done with different mobile phase was fractionated and recorded.
Gas chromatography-mass spectrometry (GC-MS)

Methanol and hexane extract of $A$. scholaris leaves were analyzed by GCMS. Perkin Elmer Clarus 680 gas chromatographic instrument equipped with a mass spectrometer detector (Clarus 600 model) and an Elite-5MS ( $30.0 \mathrm{~m}, 0.25 \mathrm{mmID}, 250 \mu \mathrm{m} \mathrm{df}$ ) column was used. The carrier gas used was helium at a flow rate of $1 \mathrm{ml} /$ minutes. The following temperature program was used: Initially, the oven temperature was held at $60^{\circ} \mathrm{C}$ for 2 minutes and then ramped from $10^{\circ} \mathrm{C} /$ minutes to $300^{\circ} \mathrm{C}$ withhold time for 4 minutes, total run time 30 minutes. The temperature of the injector was maintained at $300^{\circ} \mathrm{C}$. The ion trap was operated at $70 \mathrm{eV}$ with a scan range of $\mathrm{m} / \mathrm{z}$ from 50 to 600 . A sample of $1 \mu \mathrm{l}$ was injected in split mode (10:1). The intermediate and end product was identified based on the Wiley registry of mass spectral data.

\section{Antimicrobial study}

The antibacterial activity of three different extracts (methanol and hexane) of $A$. scholaris plant leaves against selected clinical bacterial pathogens was evaluated using agar well diffusion method [11,12]. Muller-Hinton Agar plates were inoculated with selected bacterium. Wells of $8 \mathrm{~mm}$ size were made with sterile borer on agar plates. Four different volumes $(25,50,75$, and $100 \mu \mathrm{l})$ of the plant extract were poured into each well of inoculated plates. The respective solvent for particular solvent extracts was used as a negative control. Then, they were left at room temperature for 10 minutes allowing the diffusion of the plant extract into the agar [13]. After incubation for $24 \mathrm{hrs}$ at $37^{\circ} \mathrm{C}$, the plates were observed for clear zone. Antibacterial activity of the extract was identified by an inhibition zone surrounding the well containing the plant extract. The zone of inhibition was measured and expressed in millimeters. Clear zone of the plant extract and comparison with negative control was recorded [14].

\section{RESULTS AND DISCUSSION}

The plant extracts obtained after soxhlet extraction by both methanol and hexane were dried completely for further analysis. The methanol and hexane extracts of $A$. scholaris were subjected to phytochemical studies to determine the presence of different bioactive compounds which was followed by GC-MS afterwards.

In A. scholaris, methanol extract possesses quinones, steroids, alkaloids, terpenoids, whereas $\mathrm{n}$-hexane possesses flavonoids, quinones, tannins, saponin, and carbohydrates. Although ferric chloride test showed negative result indicating the absence of phenolic compounds as well as methanol extract showed a negative result for glycosides. The phytochemical profile of both the extracts is presented in Table 1.

The presence of alkaloids has been seen in the extract as it is reported in the previous studies by Dey [15]. Among different alkaloids, echitamine, picrinine, mataranine $\mathrm{A}$, and monoterpenoid indole alkaloids have been reported. Constituents have been reported from different parts of the tree as bark, leaves, roots, fruits, and flowers [16].

Table 1: Phytochemical profile of plant extracts

\begin{tabular}{llll}
\hline \multirow{2}{*}{$\begin{array}{l}\text { Serial } \\
\text { number }\end{array}$} & Phytochemical tests & \multicolumn{2}{l}{ Alstonia scholaris } \\
\cline { 3 - 4 } & & $\begin{array}{l}\text { Methanol } \\
\text { extract }\end{array}$ & $\begin{array}{l}\text { Hexane } \\
\text { extract }\end{array}$ \\
\hline 1 & Phenol test & - & - \\
2 & Flavanoids & - & + \\
3 & Quinones & + & + \\
4 & Tannins & - & + \\
5 & Steroids & + & - \\
6 & Alkaloids & + & - \\
7 & Saponin & - & + \\
8 & Terpenoids & + & - \\
9 & Proteins & - & - \\
10 & Carbohydrates- Fehling A & - & + \\
11 & Carbohydrates- Fehling B & - & - \\
\hline
\end{tabular}

+ indicate presence of the compound, - indicate absence 
The presence of flavonoids, quinolones, tannins, and terpenoids has also been observed in the extract. According to the other research work, sookanin-7-o-alpha-l rhamnopyranoside, a new flavanone glycoside [17] and alstonoside, and a secoiridoid glucoside [18] have been recorded. Iridoids, coumarins, flavonoids, leucoanthocyanins, reducing sugars, simple phenolics, steroids, saponins, and tannins were also found in the plant has reported the presence of alkaloids in extract.

The TLC was conducted to analyze the separation of phytochemical constituents present in plant extracts according to their different Rf values. To separate the components present in plant extracts, various solvent system were employed but toluene:ethyl-acetate:methanol (4:0.5:0.5) and hexane:ethyl acetate (9:1) showed best separation for methanol extracts and hexane extract, respectively. The Rf value was calculated and has been presented in Table 2 .

The antibacterial activity of both the extracts of A. scholaris was determined through well-diffusion method at varying concentration $10-40 \mathrm{mg} / \mathrm{ml}$. The methanol extracts showed good antimicrobial effect against all pathogenic microorganisms while hexane extracts did not show effective antimicrobial effect. The zone of inhibition obtained

Table 2: Rf values of the separated spots

\begin{tabular}{llll}
\hline Extract & $\begin{array}{l}\text { Solvent } \\
\text { run }\end{array}$ & $\begin{array}{l}\text { Distance covered } \\
\text { by spots (in cm) }\end{array}$ & $\begin{array}{l}\text { Rf values } \\
\text { (mean } \pm \text { SD) }\end{array}$ \\
\hline A. scholaris & $4.2 \mathrm{~cm}$ & 0.3 & $0.072 \pm 0.3$ \\
methanol extract & & & \\
& & 0.6 & $0.143 \pm 0.2$ \\
& & 0.8 & $0.190 \pm 0.5$ \\
& & 1.0 & $0.238 \pm 0.1$ \\
& & 2.7 & $0.455 \pm 1$ \\
& & 3.95 & $0.642 \pm 0.3$ \\
& & $0.94 \pm 0.6$ \\
\hline
\end{tabular}

SD: Standard deviation, A. scholaris: Alstonia scholaris from plant extract was compared with standard antibiotic ampicillin which showed the similar antimicrobial effect when compare to ampicillin. A. scholaris showed the highest activity against Bacillus subtilis, followed by Staphylococcus sp. and it showed the least activity against Streptococcus sp. and Pseudomonas sp.. The related result has been reported by Khyade and Vaikos [19]. The antibacterial activity of both the extract is presented in Table 3 .

The differences in the observed activities of the various extracts may be due to varying degree of solubility of the active constituents in the four solvents used. It has been documented that different solvents have diverse solubility capacities for different phytochemical constituents [20]. Demonstration of antibacterial activity of plant extract against test bacteria is an indication that the possibility of sourcing alternative antibiotic substances in this plant for the development of newer antibacterial agents. Bacteria used in this study are associated with different type of infections including wounds, burns, typhoid fever, cough, urinary infection, and skin infections.

The gas chromatogram result of methanol extract of $A$. scholaris showed that the presence of different compounds as shown in Fig. 1.

The standard data of bioactivity and drug-likeness of few commercial antibiotics have been presented in Table 4 and compared with methanol extract of $A$. scholaris in Table 5.

From the seven compounds identified in GC-MS analysis of crude methanol extract of $A$. scholaris three of them follows Lipinski rule of five, and therefore, can be potent drug agent. These include trifluoromethyl t-butyl disulfide, 2-ethylhexyl-2, 2-dichloroacetate, and phytol. Taraxasterol can also be a potent drug agent but due to high partition coefficient, it will have less bioavailability. On comparing the standard bioactivity table, it is found that all compounds identified via GC-MS have significant bioactivity mainly due to ion channel modulation and kinase inhibitor. Almost all compounds identified in GC-MS show good values of enzyme inhibitor parameter of bioactivity.

Table 3: Minimum inhibitory concentration of methanol extracts of $A$. scholaris

\begin{tabular}{llllll}
\hline Concentration $(\mathrm{mg} / \mathrm{ml})$ & B. subtilis & P. aeruginosa & S. aureus & E. coli & K. pneumonia \\
\hline 10 & $8 \pm 0.5$ & $8 \pm 0.1$ & $11 \pm 0.7$ & $13 \pm 0.7$ & $12 \pm 0.7$ \\
20 & $9 \pm 0.73$ & $8 \pm 0.13$ & $11 \pm 0.67$ & $13 \pm 0.66$ & $12 \pm 0.65$ \\
30 & $10 \pm 0.23$ & $9 \pm 0.2$ & $12 \pm 0.9$ & $14 \pm 0.9$ & $13 \pm 0.89$ \\
40 & $11 \pm 0.9$ & $9 \pm 16$ & $12 \pm 0.33$ & $14 \pm 0.33$ & $13 \pm 0.3$ \\
Ampicillin & 20 & 15 & 16 & 17.5 & 20 \\
\hline
\end{tabular}

B. subtilis: Bacillus subtilis, P. aeruginosa: Pseudomonas aeruginosa, S. aureus: Streptococcus aureus, E. coli: Escherichia coli, K. pneumonia: Klebsiella pneumonia, A. scholaris: Alstonia scholaris

Table 4: Standard values of bioactivity and drug likeness of some antibiotics

\begin{tabular}{|c|c|c|c|c|c|c|c|c|c|}
\hline Compound & $\begin{array}{l}\text { GPCR } \\
\text { ligand }\end{array}$ & $\begin{array}{l}\text { Ion channel } \\
\text { modulation }\end{array}$ & $\begin{array}{l}\text { Kinase } \\
\text { inhibitor }\end{array}$ & $\begin{array}{l}\text { Nuclear receptor } \\
\text { inhibitor }\end{array}$ & $\begin{array}{l}\text { Protease } \\
\text { inhibitor }\end{array}$ & $\begin{array}{l}\text { Enzyme } \\
\text { inhibitor }\end{array}$ & $\begin{array}{l}\log p \\
\text { value }\end{array}$ & $\begin{array}{l}\text { Molar } \\
\left.\text { refractivity (in } \mathrm{cm}^{3}\right)\end{array}$ & $\begin{array}{l}\text { Drug likeness } \\
\text { model score }\end{array}$ \\
\hline Ampicillin & 0.04 & -0.47 & -0.71 & -0.61 & 0.87 & 0.25 & 0.68 & $89.94 \pm 0.4$ & 1.05 \\
\hline Gentamycin & 0.34 & 0.19 & 0.18 & -0.06 & 0.66 & 0.46 & 0.59 & $122.64 \pm 0.4$ & 1.10 \\
\hline Ofloxacin & 0.23 & -0.14 & -0.06 & -0.13 & -0.26 & 0.35 & 1.13 & $91.09 \pm 0.4$ & 1.62 \\
\hline
\end{tabular}

GPCR: G protein-coupled receptor

Table 5: Bioactivity and drug likeness values of crude methanol extract of Alstonia scholaris

\begin{tabular}{|c|c|c|c|c|c|c|c|}
\hline Compound name & $\begin{array}{l}\text { Molecular } \\
\text { Formula }\end{array}$ & $\begin{array}{l}\text { Molecular } \\
\text { weight }\end{array}$ & HBA & HBD & $\begin{array}{l}\text { Drug } \\
\text { likeness }\end{array}$ & $\log p$ & $\begin{array}{l}\text { Molar } \\
\text { refractivity }\end{array}$ \\
\hline Trifluoromethyl t-butyl Disulfide & $\mathrm{C}_{5} \mathrm{H}_{9} \mathrm{~F}_{3} \mathrm{~S}_{2}$ & 190.01 & 2 & 0 & -2.63 & 2.63 & $41.62 \pm 0.3$ \\
\hline 2-Ethylhexyl-2,2-dichloroacetate & $\mathrm{C}_{10}^{5} \mathrm{H}_{18} \mathrm{C}_{12}^{2} \mathrm{O}_{2}$ & 240.07 & 2 & 0 & -1.07 & 3.49 & $59.76 \pm 0.6$ \\
\hline 3,4-dimethoxyoxane-2,5-Diol & $\mathrm{C}_{7} \mathrm{H}_{14} \mathrm{O}_{5}$ & 178.08 & 5 & 2 & -0.68 & -1.30 & $40.61 \pm 0.9$ \\
\hline 1-Methylcyclohexane-1,2,3,4,5,6-hexol (Myoinositol) & $\mathrm{C}_{7} \mathrm{H}_{14}^{14} \mathrm{O}_{6}^{5}$ & 194.08 & 6 & 6 & -1.60 & -1.55 & $41.82 \pm 0.89$ \\
\hline Trans, cis-1,8-Dimethylspiro $[4,5]$ decane & $\mathrm{C}_{12}^{7} \mathrm{H}_{22}^{14}$ & 166.17 & 0 & 0 & -0.42 & 2.49 & $53.48 \pm 0.77$ \\
\hline (Z,7R,11R)-3,7,11,15- tetramethylhexadec-2-enol (Phytol) & $\mathrm{C}_{20}^{12} \mathrm{H}_{40}^{22} \mathrm{O}$ & 296.31 & 1 & 1 & -0.98 & 5.23 & $96.01 \pm 0.2$ \\
\hline
\end{tabular}




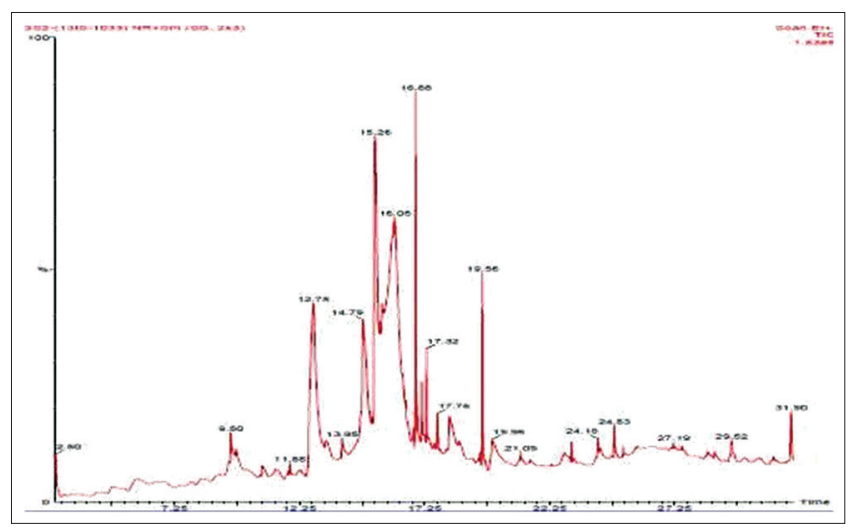

Fig. 1: Gas chromatography mass spectrometry chromatogram of Alstonia scholaris methanol extract

\section{CONCLUSION}

From this study, A. scholaris is proven to be rich in different secondary metabolites such as flavonoids, alkaloids, tannins, terpenoids, and saponin which exhibit antimicrobial activity. The plant extract can be used as drugs to treat pathogenic infection though more research is needed to identify and purify the bioactive compounds.

\section{REFERENCES}

1. Radji M, Agustama RA, Elya B, Tjampakasari CR. Antimicrobia activity of green tea extract against isolates of methicillin-resistant Staphylococcus aureus and multi-drug resistant Pseudomonas aeruginosa. Asian Pac J Trop Biomed 2013;3(8):663-7.

2. Talbot GH1, Bradley J, Edwards JE Jr, Gilbert D, Scheld M, Bartlett JG. Antimicrobial availability task force of the infectious diseases society of America bad bugs need drugs: An update on the development pipeline from the antimicrobial availability task force of the infectious diseases Society of America. Clin Infect Dis 2006;42(5):657-68.

3. Kiddee A, Henghiranyawong K, Yimsabai J, Tiloklurs M, Niumsup PR. Nosocomial spread of class 1 integron-carrying extensively drugresistant Pseudomonas aeruginosa isolates in a Thai hospital. Int $\mathrm{J}$ Antimicrob Agents 2013;42(4):301-6.
4. Chauhan R, Abraham J. In vitro antimicrobial potential of the Lichen Parmotrema sp. Extracts against various Pathogens. Iran J Basic Med Sci 2013;16(4):882-5.

5. Kamba AS, Hassan LG. Phytochemical Screening and Antimicrobial Activities of Euphorbia balsamifera leaves, stems and root against some pathogenic microorganism. J Pharm Pharmacol 2010;4(9):645-52.

6. Evans WC. Pharmacology. Trease and Evans Pharmacognosy. Asia, Singapore: Harcourt Brace and Company; 1997. p. 226-8.

7. Wagner H. Pharmazeutische Biology. AUFI. 15 BN 3- 437-20 498-X $5^{\text {th }}$ ed. Stuttgart, Germany: Gustav Fisher Vwelag; 1993. p. 184.

8. Ramakishana W, Lagu MD, Gupta VS, Ranjekar PK. DNA fingerprinting in rice using oligonucleotide probes specific for simple repetitive DNA sequences. Theor Appl Genet 1994;88(3-4):402-6.

9. Finar IL. Stereo Chemistry and Chemistry of Natural Products. Vol. 2. Singapore: Longman; 1986. p. 682

10. Mace ME. Histochemical localization of phenols in healthy and diseased banar roots. Physiol Plant 1963;16:915-25.

11. Ahmad I, Beg AZ. Antimicrobial and phytochemical studies on 45 Indian medicinal plants against multi-drug resistant human pathogens. J Ethnopharmacol 2001;74(2):113-23.

12. Srinivasan D, Nathan S, Suresh T, Lakshmana Perumalsamy $P$. Antimicrobial activity of certain Indian medicinal plants used in folkloric medicine. J Ethnopharmacol 2001;74(3):217-20.

13. Rios JL, Recio MC, Villar A. Screening methods for natural products with antimicrobial activity: A review of the literature. J Ethnopharmacol 1988;23(2-3):127-49.

14. Hammer KA, Carson CF, Riley TV. Antimicrobial activity of essential oils and other plant extracts. J Appl Microbiol 1999;86(6):985-90.

15. Dey A. Alstonia scholaris R.Br. (Apocynaceae): Phytochemistry and pharmacology: A concise review. J Appl Pharm Sci 2011;1(6):51-7.

16. Hirasawa Y, Miyama S, Kawahara N, Goda Y, Rahman A, Ekasari W, et al. Indole alkaloids from the leaves of Alstonia scholaris. Heterocycles 2009;79:1107-12.

17. Chauhan JS, Chaturvedi R, Kumar S. Isookanin-7-O-alphalrhamnopyranoside a new flavanone glycoside from the Roots of Alstonia scholaris. Indian J Chem B Org Chem Incl Med Chem 1985;24(2):219.

18. Thomas PS, Kanaujia A, Ghosh D, Duggar R, Katiyar CK. Alstonoside, a secoiridoid glucoside from Alstonia scholaris. Indian J Chem B Org 2008;47:1298-302.

19. Khyade MS, Vaikos NP. Phytochemical and antibacterial properties of leaves of Alstonia scholaris R. Br. Afr J Biotechnol 2009;8(22):6434-6.

20. Cowan MM. Plant products as antimicrobial agents. Clin Microbiol Rev 1999;12(4):564-82. 